\title{
THE ENVIRONMENTAL PERFORMANCE OF AGRICULTURAL FARMS IN RELATION TO THEIR SECTOR AND PRODUCTION SYSTEM
}

\author{
M. Topchieva* \\ Economics of Natural Resources Department, University of National and World Economy, Sofia, \\ Bugaria
}

\begin{abstract}
Greenhouse gas emissions, nitrogen and phosphorus emissions to water, air and soil are agriculture's main environmental externalities, which contribute to significant negative impacts, such as climate change, water and terrestrial eutrophication and loss of biodiversity, among others. The environmental performance of agricultural farms differs significantly depending on the sector, on the production system, and on the applied production practices. Therefore, the potential for reduction of the farms' negative environmental impacts varies significantly. By means of literature review and analysis, the article aims to present an overview of the environmental impacts of the agricultural farms, considering their sector and production system. As a result, an outline of farms with the lowest to highest negative environmental impact is presented. This distinction allows for further analysis of the factors contributing to the most polluting and resource-intensive production practices in agriculture. In conclusion, mitigation potentials and opportunities for improving the environmental performance of farms are given, with relevance to the specific sectors and production systems.
\end{abstract}

Key words: agriculture, environmental sustainability, production practices, impact mitigation

\section{INTRODUCTION}

During the second half of the $20^{\text {th }}$ century the global food production more than doubled and thus responded to the doubling of world population. Global cropland, plantations and pastures expanded, causing large increases in in fossil energy, water and fertilizer inputs. This generated significant footprint on the environment, on the ecosystems health and productivity (1). Agriculture is unique among the sectors of the economy because of the strong two-way relationship with the environment. It is, on the one hand, affected by the environmental conditions, as the quantity and quality of commodities produced by agriculture, highly depend on climate, precipitation, water availability and other factors of the environment. On the other hand, the sector significantly impacts these conditions. Generating greenhouse gas emissions, nitrogen and phosphorus emissions

\footnotetext{
*Correspondence to: Mariya Topchieva, Economics of Natural Resources Department, University of National and World Economy, Sofia, Bugaria, 1700 Students' Town, Osmi Dekemvri Street, UNWE, +359883599192, maria_topchieva@abv.bg
}

to water, air and soil, makes the sector one of the largest contributors to negative impacts, such as climate change, water and terrestrial eutrophication, soil acidification, loss of biodiversity. However, not all sub-sectors of agriculture contribute equally to these negative impacts. Furthermore, there is evidence that the sizes of impacts differ even when they refer to similar products or systems. This is why it is critical to analyze the factors that contribute to the results and hot spots of the different production systems, so that relevant measures are taken in order to minimize the negative environmental externalities and to optimize the overall performance of farming systems.

\section{METHODS}

The goal of this research is to present an overview of the main environmental impacts of agricultural farms and products with reference to their sector and production system. Which farming systems and products generate the highest environmental burdens and which are the main mitigation opportunities for the different sectors and production systems, are the main questions that the study is investigating. The methods used include literature review and analysis of articles from 
TOPCHEVA $M$.

scientific databases and journals that assess, compare or optimize the environmental impacts of farms from different sectors and production systems. Life cycle assessment (LCA) has been chosen for a method for evaluation of the environmental performance of farms and agricultural products. LCA is a generally accepted method to evaluate the environmental impact during the life cycle of a product, process or system (2). It has been widely used in agriculture in order to assess the ecological sustainability of food products and production systems, to identify hot spots in their environmental performance and to recommend more sustainable practices. Main advantages of LCA are that is allows covering a broad system boundary and the broadest range of environmental impacts and therefore, it avoids burden shifting between the life cycle stages and the environmental impacts. LCA covers environmental impacts such as climate change, ozone depletion, human toxicity, acidification, terrestrial eutrophication, freshwater eutrophication, marine eutrophication, freshwater eco-toxicity, land use, water resource depletion, resource depletion, particulate matter formation, ionizing radiation, photochemical ozone formation and others.

\section{RESULTS \\ 1. Environmental impacts of agricultural products in relation to their sector}

A comparison of the environmental impacts of the most representative food and beverage products consumed in the EU-27 has been conducted by the Institute of Environment and Sustainability at the Joint Research Centre and the University of Bari (3). 17 products are included in the assessed product basket, such as meat, dairy, fruits, vegetables and their derivatives. The environmental impact assessment is performed via lifecycle assessment (LCA) with "cradle-to-grave" system boundaries for 12 impact categories. The results reflect two factors: the environmental impacts of the specific foods and the quantity of their relative consumption per capita in Europe in 2010. The results of the study indicate that in the majority of the impact categories, meat products (beef, pork and poultry) and dairy products (cheese, milk and butter) have the greatest burdens at EU-27 level. Beef meat has the highest environmental impact in the basket of products due to its high environmental impact per $\mathrm{kg}$, even though it has the lowest annual consumption per capita of all meat products. Pork meat has environmental impact as high as beef, although it has lower environmental impact per $\mathrm{kg}$, which is counterbalanced by higher per-capita consumption. The case with dairy products is similar to the case of pork meat. Fruits have the smallest contribution to the overall result and all other foods fall between these two profiles. Concerning the contribution of the lifecycle stages to the impact categories, the agricultural production stage has the greatest environmental burden in many of the impact categories. This is due to the high energy consumption and the associated "emissions of greenhouse gases, particulate matter, ammonia, sulphur dioxide, nitrogen oxide and heavy metals" (3). Processing and logistics are the next most burdening stages, followed by packaging, use and end-of-life.

Another study has compared the nitrogen footprint of food products in the EU-25 using the CAPRI model (4). The nitrogen footprint is defined as the total losses of reactive nitrogen (N) to the environment per unit of product and it is related to environmental impacts such as acidification and eutrophication of water and soil. The results indicate that the nitrogen footprint varies widely between different food categories with substantially higher values for livestock products, as compared to vegetable products. For EU-25, ruminant meat has the highest nitrogen footprint of all food products and equals $500 \mathrm{~g} \mathrm{~N} / \mathrm{kg}$ product. It is followed by pork and poultry meat at $100 \mathrm{~g} \mathrm{~N} / \mathrm{kg}$ product and eggs and milk between 30 and 50 $\mathrm{g} \mathrm{N} / \mathrm{kg}$ product. For the vegetable products the ranking is: oilseeds with $20 \mathrm{~g} \mathrm{~N} / \mathrm{kg}$ product, cereals and pulses with $10 \mathrm{~g} \mathrm{~N} / \mathrm{kg}$ product, sugar beet, fruits and vegetables, and potatoes with 2-3 g N/ kg product.

Livestock production systems currently occupy around $65 \%$ of the agricultural land in EU-27 and affect water, air and soil quality, global climate and biodiversity. They alter the biogeochemical cycles of nitrogen, phosphorus and carbon and cause nutrient imbalances with large surpluses in Europe and China and soil nutrient depletion in Africa and South America (5), (6). Leip et al. calculated that the livestock sector contributes significantly to agricultural environmental effects in Europe, namely: $78 \%$ of terrestrial biodiversity loss, $80 \%$ for soil acidification and air pollution (ammonia and nitrogen oxides emissions), $81 \%$ of greenhouse gas emissions and $73 \%$ of water pollution (both nitrogen and phosphorus emissions) (5). Major contribution for these impacts is made 
by feed production, including feed imports from other countries outside of the EU-27.

Cereal crops represent the most important group of food crops produced throughout the world. In fact, fewer than 20 plant species provide $90 \%$ of mankind's food supply, and cereals account for approximately two thirds of all human calorie intake. However, cereal product systems entail particular environmental hot spots originating from their widespread use and from their particular nature (7). In modern agriculture cereal crops are generally grown in monoculture and are characterized by a relative instability, because they show high leaching loss of nutrients, they are susceptible to invasions by weed species and have high incidence of disease and pest (8). Therefore, their cultivation contributes to the environmental impacts: climate change, acidification, water and terrestrial eutrophication, ozone layer depletion, eco-toxicity and resource depletion (7), (8). In view of the life cycle of cereal production, the cultivation phase is the one with largest contribution for the environmental impacts (7). This has been confirmed by Fantin et al., who calculated that the agricultural phase contributes to the total impact results of wheat with $96 \%$ and with $91 \%$ for maize. This is mainly due to the production, transport and packaging of fertilizers and the on-field emissions from their spreading on agricultural land (8).

A comparison between the greenhouse gas emissions of typical production systems in the crop and livestock sectors in the UK is presented by Audsley and Wilkinson (9). They calculated the following greenhouse gas emissions of typical crop systems, arranged from lowest to highest $\mathrm{CO}_{2}$-equivalent per $\mathrm{kg}$ of product: sugar beet $\left(0,04 \mathrm{~kg} \mathrm{CO}{ }_{2}\right.$-eq/ $\mathrm{kg} ; 2,87 \mathrm{~kg} \mathrm{CO}_{2}$-eq/ $\mathrm{kg}$
TOPCHEVA $M$.

crude protein), second early potatoes $(0,10 \mathrm{~kg}$ $\mathrm{CO}_{2}$-eq/ kg; 5,38 $\mathrm{kg} \mathrm{CO}$-eq/ $\mathrm{kg}$ crude protein), main crop potatoes $(0,14 \mathrm{~kg} \mathrm{CO}$-eq $/ \mathrm{kg} ; 7,53 \mathrm{~kg}$ $\mathrm{CO}_{2}$-eq/ $\mathrm{kg}$ crude protein), forage maize $(0,30 \mathrm{~kg}$ $\mathrm{CO}_{2}$-eq/ kg; $2,97 \mathrm{~kg} \mathrm{CO}$-eq/ $\mathrm{kg}$ crude protein), maize grain $\left(0,38 \mathrm{~kg} \mathrm{CO}_{2}\right.$-eq/ $\mathrm{kg} ; 4,33 \mathrm{~kg} \mathrm{CO}_{2^{-}}$ eq/ $\mathrm{kg}$ crude protein), spring barley $(0,38 \mathrm{~kg}$ $\mathrm{CO}_{2}$-eq/ $\mathrm{kg} ; 3,81 \mathrm{~kg} \mathrm{CO}$-eq/ $\mathrm{kg}$ crude protein), winter barley $\left(0,42 \mathrm{~kg} \mathrm{CO}_{2}\right.$-eq/ $\mathrm{kg} ; 3,97 \mathrm{~kg} \mathrm{CO}_{2}$ eq/ $\mathrm{kg}$ crude protein), winter feed wheat $(0,46 \mathrm{~kg}$ $\mathrm{CO}_{2}$-eq/ kg; 4,61 kg CO${ }_{2}$-eq/ kg crude protein), winter bread wheat $\left(0,51 \mathrm{~kg} \mathrm{CO}_{2}\right.$-eq/ $\mathrm{kg} ; 4,56 \mathrm{~kg}$ $\mathrm{CO}_{2}$-eq/ $\mathrm{kg}$ crude protein), field beans $(0,51 \mathrm{~kg}$ $\mathrm{CO}_{2}$-eq/ kg; $1,99 \mathrm{~kg} \mathrm{CO}$-eq/ kg crude protein), soya beans $\left(0,70 \mathrm{~kg} \mathrm{CO}\right.$-eq/ $\mathrm{kg} ; 1,96 \mathrm{~kg} \mathrm{CO}_{2}$-eq/ $\mathrm{kg}$ crude protein), winter oilseed rape $(1,05 \mathrm{~kg}$ $\mathrm{CO}_{2}$-eq/ kg; $5,33 \mathrm{~kg} \mathrm{CO}_{2}$-eq/ kg crude protein). The estimated greenhouse gas emissions from typical livestock systems, arranged from lowest to highest $\mathrm{CO}_{2}$-equivalent per $\mathrm{kg}$ of product, are as follows: milk $(1,0 \mathrm{~kg} \mathrm{CO}$-eq/ $\mathrm{kg} ; 30,6 \mathrm{~kg}$ $\mathrm{CO}_{2}$-eq/ $\mathrm{kg}$ edible protein), poultry meat $(2,7 \mathrm{~kg}$ $\mathrm{CO}_{2}$-eq/ kg; $14,2 \mathrm{~kg} \mathrm{CO}$-eq/ kg edible protein), eggs $\left(3,0 \mathrm{~kg} \mathrm{CO}\right.$-eq/ kg; 23,2 kg CO${ }_{2}$-eq/ $\mathrm{kg}$ edible protein), pig meat $\left(4,0 \mathrm{~kg} \mathrm{CO} \mathrm{CO}_{2}\right.$-eq/ $\mathrm{kg}$; $19,7 \mathrm{~kg} \mathrm{CO}$-eq/ $\mathrm{kg}$ edible protein), dairy beef $\left(8,5 \mathrm{~kg} \mathrm{CO}{ }_{2}\right.$-eq/ kg; $49,5 \mathrm{~kg} \mathrm{CO}$ CO$_{2}$-eq $\mathrm{kg}$ edible protein), sheep meat $(14,6 \mathrm{~kg} \mathrm{CO}$-eq/ $\mathrm{kg} ; 69,3$ $\mathrm{kg} \mathrm{CO}_{2}$-eq/ $\mathrm{kg}$ edible protein) and suckler beef (15,9 kg CO CO $_{2} / \mathrm{kg} ; 90,0 \mathrm{~kg} \mathrm{CO}$-eq/ kg edible protein). Livestock products have significantly higher carbon footprint compared to crop products when the comparison is made per $\mathrm{kg}$ of product; and the difference is still big when the comparison is made for $\mathrm{kg}$ edible protein. The data on the greenhouse gas emissions of typical production systems from the cited study is visualized in Figure 1.

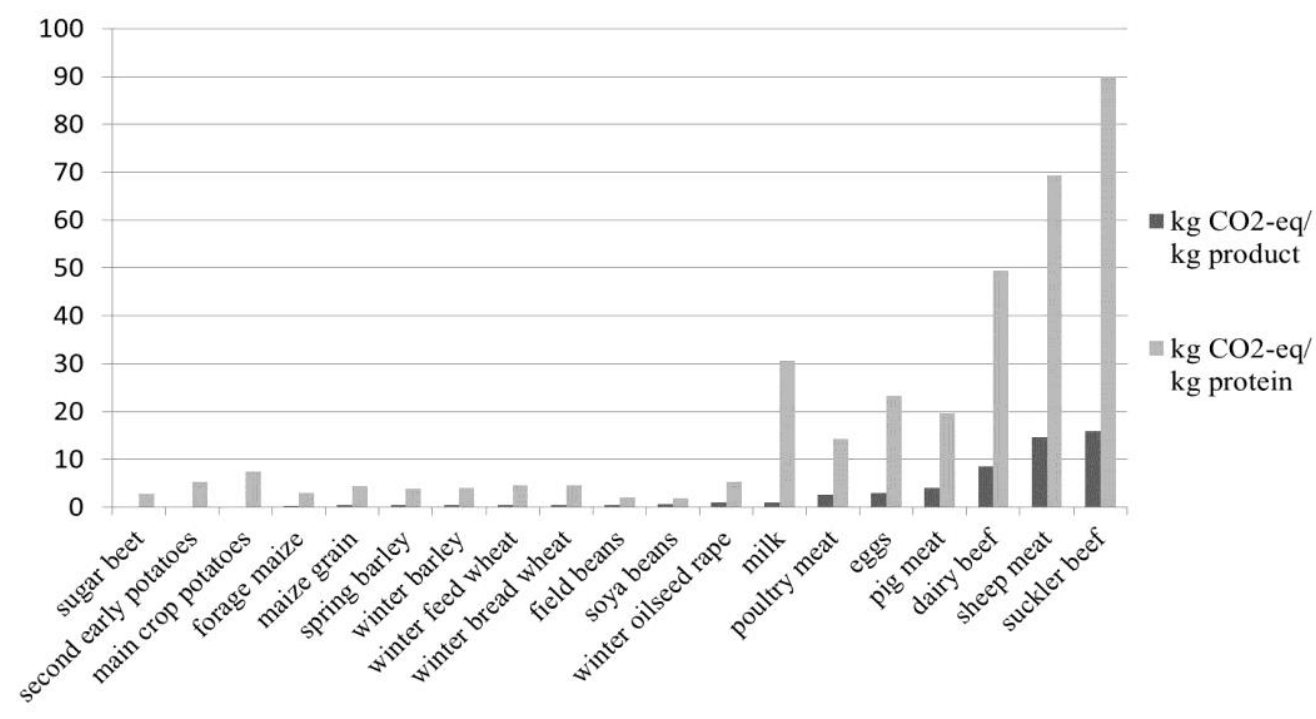

Figure 1. Greenhouse gas emissions of typical production systems in crop and livestock sectors in the UK Data source: Audsley and Wilkinson (9) 
Lesschen et al. (6) examine the impact category of greenhouse gas emissions for the livestock sub-sectors in the EU-27. The authors calculated the average emission intensity per $1 \mathrm{~kg}$ of product in the EU-27: beef $(22,6 \mathrm{~kg} \mathrm{CO}$-eq $/ \mathrm{kg})$, pork $\left(3,5 \mathrm{~kg} \mathrm{CO} 2^{-}\right.$ $\mathrm{eq} / \mathrm{kg})$, eggs $(1,7 \mathrm{~kg} \mathrm{CO}$-eq/kg), poultry $(1,6$ $\mathrm{kg} \mathrm{CO}{ }_{2}$-eq $\left./ \mathrm{kg}\right)$ and milk $\left(1,3 \mathrm{~kg} \mathrm{CO} \mathrm{CO}_{2}\right.$-eq/kg). Summarized by sub-sector, the largest emissions are generated by dairy and beef, which together account for more than $70 \%$ of the greenhouse gas emissions from livestock in the EU-27. The share of the greenhouse gas emissions from the pig sub-sector is $16 \%$ and the poultry sector is $6 \%$. The distribution of greenhouse gas emissions per emission sources is as follows: enteric fermentation (36\%), emissions from agricultural soils (28\%), manure storage $(13 \%)$, fertilizer production (11\%), cultivation of organic soils and liming (7\%), fossil fuel use $(3,2 \%)$ and electricity $(3,2 \%)$. The authors indicate that the contribution of livestock sub-sectors and emission sources differs significantly among countries. There are large differences among farms in animal productivity and environmental impacts, which are partially due to differences in animal production systems, feed types and nutrient use efficiencies by the animals.

The increase in the consumption of animal products increases the pressure on the world's freshwater resources as well. Mekonnen and Hoekstra (10) estimated the global averages of the water footprint of the main livestock categories. The water footprint is an indicator comprising of three sub-categories: blue water footprint (consumption of surface and groundwater along the supply chain of a product), green water footprint (consumption of rainwater) and grey water footprint (volume of polluted freshwater). Globally, the total water footprint of animal production constitutes $29 \%$ of the water footprint of total agricultural production, of which beef is responsible for $33 \%$, dairy cattle for $19 \%$, pigs for $19 \%$ and broiler chickens for $11 \%$. The distribution of the global water footprint per production systems is the following: mixed production systems have largest share with $57,4 \%$, industrial production systems account for $22,3 \%$ and grazing systems account for $20,3 \%$. The authors calculated that beef had the highest water footprint $\left(15400 \mathrm{~m}^{3} / \mathrm{ton}\right)$, followed by sheep meat $\left(10400 \mathrm{~m}^{3} / \mathrm{ton}\right)$, pig meat $\left(6000 \mathrm{~m}^{3} /\right.$ ton $)$, goat meat $\left(5500 \mathrm{~m}^{3} /\right.$ ton $)$ and chicken meat $\left(4300 \mathrm{~m}^{3} / \mathrm{ton}\right)$. The water footprint of any animal product is higher than the water footprint of crop products with equivalent nutritional value. Beef, for example, has twenty times larger water footprint than cereals and starchy roots per calorie and a gram of protein from pulses has 1,5 times smaller water footprint than from milk, eggs and chicken meat and 6 times smaller footprint than a gram of protein from beef. This is why, from a freshwater perspective, it is more efficient to obtain calories, protein and fat through crop products than from animal products (10).

\section{Environmental performance of farms in relation to their production system}

A growing number of LCA studies have compared the environmental impacts of the same products produced in organic and in conventional farming systems (11). Van Stappen et al. performed a LCA comparing the environmental impact of wheat production produced in organic and conventional systems (12). In their study they used two types of functional unit: mass (1 kg of grains) and area (1 ha) and the results they obtained were very sensitive to the choice of functional unit. When using 1 ha as a functional unit, the organic wheat achieved better environmental performance results than conventional wheat in the impact categories: global warming potential, photochemical oxidant formation and cumulative energy demand. However, when the functional unit was $1 \mathrm{~kg}$ of grains, the conventional wheat achieved better environmental performance than organically produced wheat in the categories: terrestrial acidification potential, eutrophication potential, agricultural land occupation and photochemical oxidant formation. These results were partially explained by yield differences $(8,5 \mathrm{t} / \mathrm{ha}$ for conventional wheat against 4,5 t/ha for organic wheat). Additionally, in the organic production system solid cattle manure was used as the sole organic fertilizer, which induced higher impacts than the mineral fertilization. The organic fertilizer made the highest contribution to most impact categories, including 51\% to global warming potential, $91 \%$ of human toxicity potential, $97 \%$ of terrestrial acidification potential, $89 \%$ of eutrophication potential, $86 \%$ of aquatic eco-toxicity potential and $53 \%$ in photochemical oxidant formation. On the other side, mineral fertilization made the highest contribution to the environmental impacts of the conventional system: $74 \%$ to global warming potential, $94 \%$ of human toxicity potential, $95 \%$ of terrestrial acidification potential, $69 \%$ of eutrophication 
potential, $63 \%$ of aquatic eco-toxicity potential, $87 \%$ of water depletion potential and $87 \%$ in photochemical oxidant formation. The next highest impact activities in the organic and conventional wheat production systems were mechanization; and pesticides production and application for the conventional production. With reference to the functional unit of analysis, the authors indicated that "the area" functional unit brings information on the intensity in the use of agricultural inputs, while the efficiency of production systems is taken into account by a "mass" functional unit. However, according to Meier et al., "this narrow view, which focuses mainly on production efficiency, may often favor products from intensive production systems, although these systems have been shown by other assessment methods to be not environmentally sustainable" (11).

Another study calculated the potential ecoefficiency gains from a transition to organic production of four major field crops at national level in Canada (13). Assumed reduction in yield rates for organic canola, corn, soy and wheat were $90 \%, 95 \%, 100 \%$ and $90 \%$. The results indicated that organic crop production would consume $39 \%$ as much energy and generate $77 \%$ of the global warming emissions, $17 \%$ of the ozone-depleting emissions and $96 \%$ of the acidifying emissions associated with current production of these crops. The results are based mainly on the different fertilizer characteristics for the two systems as green manure has been chosen for the organic production compared to conventional synthetic nitrogen fertilizer.

Meier et al. indicate that many LCA studies comparing the environmental sustainability of agricultural products between conventional and organic production systems, report a wide variation in the results (11). For this reason and in order to draw general conclusions on the environmental performance of the two product systems, they performed an analysis of 34 comparative LCA studies comparing identical products, produced in conventional and in organic systems. Of all 34 studies, 3 studies showed higher yields for organic production systems; 1 study reported the same yield for both systems; and all the other studies reported higher yields for the conventional production systems. Organic products had generally lower environmental impacts on a per area unit for all analyzed impact categories with several exceptions (organic bean - all categories except for aquatic ecotoxicity; organic beef, pig and poultry - abiotic resource use, acidification and eutrophication potential; organic tomatoes - energy demand, acidification and eutrophication potential; organic wheat and potatoes - eutrophication and acidification potential; organic strawberries - global warming potential). However, for the same impact categories and the same commodity, the environmental impacts reported in the reviewed LCA studies varied considerately, which did not allow the authors to draw general conclusions on which production system gives better environmental results and to what extent.

\section{Environmental performance of farms in relation to their production practices}

Altering agricultural practices to meet sustainability criteria can be a promising solution for reducing environmental burdens related to agricultural management practices (14). Various studies explore the mitigation potential of different production practices in arable crop production through changing soil tillage systems, fertilizer type and spreading techniques, crop residue management and crop rotations. Nemecek et al. investigated the potentials for reducing the environmental impacts of cropping systems through different crop combinations (15). They found out that diversification of crop rotations together with improved nitrogen management is an option for achieving more eco-efficient cropping systems. Nitrogen management revealed to be a key driver for the environmental impacts of crops. Introduction of pea allowed reducing the total eutrophication over the whole crop rotation. Catch crops had favorable effects on nutrient leaching and slightly favorable effects on biodiversity and soil quality. The authors concluded that diverse crop rotations with reduced input of nitrogen proved to be generally favorable from an environmental point of view. However, a trade-off between environmental and economic goals was identified in the study.

In the field of livestock production, LCA studies have explored the potential improvement of the environmental performance of farms through changing the animal breed, type of production, animal diet, feed origin, etc. Vries et al. compared the environmental impacts of beef production systems differentiated by three main characteristics and production practices: origin of calves (bred by a dairy cow or a suckler cow), type of production (organic or nonorganic) and type of diet fed to fattening calves 
(roughage-based or concentrate-based) (2). The results indicated that the dairy-based systems have lower global warming potential (49\% lower), energy use (23\% lower) and land use (49\% lower) per $1 \mathrm{~kg}$ of beef compared to suckler-based systems. Organic production systems achieved lower global warming potential (7\% lower) and energy use (30\% lower), although they showed higher eutrophication potential (36\% higher), acidification potential (56\% higher) and land use (22\% higher) per $1 \mathrm{~kg}$ of beef compared to non-organic systems. Concentrate-based systems achieved lower global warming potential $(28 \%)$, energy use $(13 \%)$ and land use (41\%) per $1 \mathrm{~kg}$ of beef compared to roughage-based systems, although no clear pattern was found for acidification and eutrophication potential. The authors concluded that dairy-based beef production has largest potential to mitigate the environmental impacts of beef, which can be further reduced by growing dairy-bred beef calves from dualpurpose cattle or from dairy cows crossed with beef breeds, improving the growth performance and feed efficiency of dairy-bred beef cattle. An additional option is to utilize by-products from human food, fiber and energy production that could help improve the growth performance of beef cattle while minimizing the environmental impacts and the competition for land between humans and animals.

\section{CONCLUSIONS}

Life cycle assessment is a method with undoubted advantages including a broad range of system boundaries and environmental impacts that it covers. It is a very useful method when it comes to identifying hot spots in a particular system and monitoring progress in time. However, despite its wide application at various levels in agriculture, it has certain limitations. Effects on biodiversity, soil quality and the multifunctionality of agriculture are still difficultly measured and hardly incorporated in LCA methods and models. Also, LCA focuses mainly on production efficiency and may often favor products from intensive production systems, although these systems may have been shown by other assessment methods to be not environmentally sustainable (11). Furthermore, due to different methodologies, assumptions, system boundaries and functional units, it is often difficult to compare the results from different LCAs, even when they concern the same commodity and production system type. Other reasons for the wide variation in LCA results include the specifics of natural systems, differing in landscape, soil type, water availability, climate, precipitation; and the high dependence of the results on the inputs in the production systems, which also may vary significantly.

Nevertheless, mitigation opportunities for agriculture's main environmental impacts have been identified in scientific literature.

Livestock production systems are a major driver of negative environmental impacts, such as climate change, air pollution, water eutrophication, soil acidification and biodiversity loss. These impacts, however, may be reduced through optimizing animal feed, altering breeds or through different amendments in the production system (2). Lesschen et al. suggest the following opportunities for greenhouse gas mitigation in the livestock sector: reducing methane emissions from enteric fermentation (by modifications in diet, use of feed additives and breeding for livestock with lower emissions); reducing methane emissions from manure (through optimized storage or anaerobic digestion); reducing emissions from agricultural soils (improved timing and matching of nutrient application to crop requirements); and finally, a shift to human diet with larger proportion of plant derived protein products and reducing livestock numbers. According to the authors, if implemented at global level, a reduction in the consumption of meat would more than halve the land needed for agriculture and the eutrophication associated with food production (6).

The environmental impacts of crop production are mainly related to fossil fuel consumption and to fertilizer application. Therefore, choice of fertilizers and of spreading techniques as well as crop residues management have the potential to deeply affect the environmental impacts caused by crop cultivation (16). Diversification of crop rotations, inclusion of legume and catch crops have been identified as opportunities to reduce the nitrogen inputs and therefore, reduce the environmental impacts of arable crops (15).

Notarnicola et al. suggest three main strategies for reducing the impacts of food supply chains: i) an environmentally sustainable increase in agricultural productivity coupled with measures that aim to reduce emissions to air, water and soil; ii) dietary changes, such as reducing the consumption of meat and dairy 
products; iii) greater efficiency in reducing food losses and managing food waste (3).

\section{ACKNOWLEDGEMENTS}

This research was carried out with the financial support of BIOGEA project, funded through the 2015-2016 BiodivERsA Co-fund Call for research proposals, with the national funders Bulgarian National Science Fund, German Federal Ministry of Education and Research and National Research Agency at the Spanish Ministry of Economy and Competitiveness.

\section{REFERENCES}

1. Khan, S., \& Hanjra, M. A., Footprints of water and energy inputs in food production-Global perspectives. Food policy, 34(2): 130-140, 2009.

2. De Vries, M. D., Van Middelaar, C. E., \& De Boer, I. J. M., Comparing environmental impacts of beef production systems: A review of life cycle assessments. Livestock Science, 178: 279288, 2015.

3. Notarnicola, B., Tassielli, G., Renzulli, P. A., Castellani, V., \& Sala, S., Environmental impacts of food consumption in Europe. Journal of cleaner production, 140:753-765, 2017.

4. Leip, A., Weiss, F., Lesschen, J. P., \& Westhoek, H., The nitrogen footprint of food products in the European Union. The Journal of Agricultural Science, 152(S1): 20-33, 2014

5. Leip, A., Billen, G., Garnier, J., Grizzetti, B., Lassaletta, L., Reis, S., Simpson, D., Sutton, M.A., De Vries, W., Weiss, F. and Westhoek, H., Impacts of European livestock production: nitrogen, sulphur, phosphorus and greenhouse gas emissions, land-use, water eutrophication and biodiversity. Environmental Research Letters, 10(11): 115004, 2015.

6. Lesschen, J. P., Van den Berg, M., Westhoek, H. J., Witzke, H. P., \& Oenema, O., Greenhouse gas emission profiles of European livestock sectors. Animal Feed Science and Technology, 166: 16-28, 2011.

7. Renzulli, P.A., Bacenetti, J., Benedetto, G., Fusi, A., Ioppolo, G., Niero, M., Proto, M., Salomone, R., Sica, D. and Supino, S., Life cycle assessment in the cereal and derived products sector. In Life Cycle Assessment in the Agri-food Sector. Springer, Cham, pp. 185-249, 2015.

8. Fantin, V., Righi, S., Rondini, I., \& Masoni, P., Environmental assessment of wheat and maize production in an Italian farmers' cooperative. Journal of cleaner production, 140: 631-643, 2017.

9. Audsley, E., \& Wilkinson, M., What is the potential for reducing national greenhouse gas emissions from crop and livestock production systems?. Journal of Cleaner production, 73: 263-268, 2014.

10.Mekonnen, M. M., \& Hoekstra, A. Y., A global assessment of the water footprint of farm animal products. Ecosystems, 15(3): 401-415, 2012.

11.Meier, M. S., Stoessel, F., Jungbluth, N., Juraske, R., Schader, C., Stolze, M., Environmental impacts of organic and conventional agricultural products-are the differences captured by life cycle assessment?. Journal of Environmental Management, 149: 193-208, 2015.

12.Van Stappen, F., Loriers, A., Mathot, M., Planchon, V., Stilmant, D., \& Debode, F., Organic versus conventional farming: the case of wheat production in Wallonia (Belgium). Agriculture and Agricultural Science Procedia, 7: 272-279, 2015.

13.Pelletier, N., Arsenault, N., \& Tyedmers, P., Scenario modeling potential ecoefficiency gains from a transition to organic agriculture: life cycle perspectives on Canadian canola, corn, soy, and wheat production. Environmental management, 42(6): 989-1001, 2008.

14.Ali, S. A., Tedone, L., \& De Mastro, G., Optimization of the environmental performance of rainfed durum wheat by adjusting the management practices. Journal of Cleaner Production, 87: 105118, 2015.

15.Nemecek, T., Hayer, F., Bonnin, E., Carrouée, B., Schneider, A., \& Vivier, C., Designing eco-efficient crop rotations using life cycle assessment of crop combinations. European Journal of Agronomy, 65: 40-51, 2015.

16.Bacenetti, J., Lovarelli, D., \& Fiala, M., Mechanisation of organic fertiliser spreading, choice of fertiliser and crop residue management as solutions for maize environmental impact mitigation. European Journal of Agronomy, 79: 107-118, 2016.

17.Audsley, E., \& Wilkinson, M., What is the potential for reducing national greenhouse gas emissions from crop and livestock production systems?. Journal of Cleaner production, 73: 263-268, 2014. 